\title{
EFEKTIVITAS PROGRAM GURU PEMBELAJAR DALAM PENINGKATAN KOMPETENSI GURU IPS SMP DENGAN MODA DARING MURNI DAN DARING KOMBINASI: STUDI EVALUATIF DAN KOMPARATIF
}

\section{EFFECTIVENESS OF GURU PEMBELAJAR PROGRAM IN IMPROVING SOCIAL STUDIES TEACHER COMPETENCE BY USING FULLY ONLINE AND BLENDED LEARNING MODE: EVALUATIVE AND COMPARATIVE STUDY}

\author{
Yasser Awaluddin \\ Social Studies Department PPPPTK PKn IPS \\ Jl. Raya Arhanud, Pendem, Junrejo, Kota Batu, Jawa Timur \\ Email: yawaluddin@gmail.com
}

Naskah diterima tanggal: 26-2-2018, disetujui tanggal: 27-3-2018

\begin{abstract}
It has been claimed that the implementation of Guru Pembelajar Program has successfully improved the participation of competent teachers. Yet, there has not been any thorough and detailed studies regarding the effectiveness of the program on each subject including social studies. This research aims to reveal whether the Guru Pembelajar Program using mode of fully online and blended learning has improved social studies teachers' competency. This research also compares the effectiveness of the two modes, and reveals participants' perception on the program. Mix method which analysed both quantitative and qualitative data was used in this study. Descriptive analysis and gap analysis were used for the quantitative part, while the qualitative aspect was carried out using pattern and theme analysis of participants' responses. Findings show that both modes effectively improved teachers' competency. There was a significant different in learning result from the two modes. However, the difference was due to the initial gap between the participants of the two modes. Participating teachers conveyed that the training was relevant with their teaching tasks and was effective in increasing their skill. In conclusion, the Teacher Learning Program implementation is effective in improving teacher competence, either by pure online mode or blended mode.
\end{abstract}

Key words: fully online learning, blended learning, teacher competence, Guru Pembelajar Abstrak: Pelaksanaan Program Guru Pembelajar telah berhasil meningkatkan kompetensi
guru yang mengikuti program tersebut. Namun, sejauh ini belum ada kajian secara
mendalam dan rinci mengenai sejauh mana tingkat efektivitas program tersebut pada
masing-masing mata pelajaran termasuk mata pelajaran IPS SMP. Penelitian ini bertujuan
untuk mengungkap apakah program guru pembelajar yang dilaksanakan dengan
menggunakan moda daring murni dan daring kombinasi berhasil meningkatkan kompetensi
guru IPS SMP. Penelitian ini juga membandingkan efektivitas kedua moda yang digunakan.
Selain itu, persepsi dan pendapat peserta mengenai pelatihan dengan moda daring murni
dan daring kombinasi juga akan diungkap. Pendekatan campuran untuk menganalisis data
baik secara kuantitatif maupun kualitatif digunakan dalam penelitian ini. Analisis deskriptif
dan analisis uji beda digunakan untuk aspek kuantitatif, sedangkan aspek kualitatif
dilaksanakan dengan menggunakan analisis tema dan pola respon peserta. Hasil analisis
data menunjukkan bahwa baik pelatihan moda daring murni maupun daring kombinasi
berhasil meningkatkan kompetensi peserta. Terdapat perbedaan hasil belajar antara moda
daring murni dan daring kombinas yang disebabkan oleh input awal yang berbeda. Peserta
menyatakan bahwa pelatihan ini relevan dengan tugas-tugas mengajar mereka dan efektif 
meningkatkan kompetensi mereka. Dengan demikian, Pelaksanaan Program Guru Pembelajar efektif dalam meningkatkan kompetensi guru, baik dilakukan dengan moda daring murni maupun moda daring kombinasi.

Kata kunci: daring murni, daring kombinasi, kompetensi guru, Guru Pembelajar.

\section{PENDAHULUAN}

Program Guru Pembelajar yang diluncurkan sejak tahun 2015 secara umum bertujuan untuk meningkatkan kompetensi pedagogik dan profesional guru secara berkesinambungan. Program ini mengarahkan guru agar menjadi guru pembelajar yang senantiasa berupaya meningkatkan kompetensinya sehingga dapat melaksanakan tugas sebagai guru dengan sebaik-baiknya. Guru diharapkan secara berkelanjutan dapat meningkatkan kompetensinya dengan mengacu pada Peraturan Menteri Pendidikan Nasional nomor 16 tahun 2007 tentang Standar Kualifikasi Akademik dan Kompetensi Guru (Kementerian Pendidikan Nasional, 2016).

Salah satu kekurangan dari program pengembangan keprofesian guru yang dilakukan di Indonesia adalah tidak adanya penilaian kebutuhan (need assessment) yang memadai sehingga program-program yang dilaksanakan kurang efektif untuk mengatasi kelemahankelemahan guru (Evans, dkk., 2009). Oleh karena itu, Program Guru Pembelajar ini diawali dengan pelaksanaan Uji Kompetensi Guru (UKG) sebagai upaya untuk mengetahui kompetensi guru saat itu. Hasil UKG tersebut digunakan sebagai dasar untuk menentukan bagian/bidang yang masih memerlukan peningkatan dan perbaikan, baik dari aspek pedagogik maupun aspek profesional. $\mathrm{Hal}$ ini bertujuan agar program peningkatan kompetensi yang dilakukan Pusat Pengembangan dan Pemberdayaan Pendidik dan Tenaga Kependidikan (PPPPTK) dapat lebih efektif karena disesuaikan dengan kebutuhan riil guru (Duncan-Howell, 2010).

Dalam Program Guru Pembelajar, kompetensi pedagogik dan kompetensi profesional dikelompokkan menjadi 10 kelompok kompetensi (KK) dan dituangkan dalam 10 modul. Patokan yang dijadikan dasar untuk menentukan apakah seorang guru masih memerlukan peningkatan pada kelompok kompetensi (modul) tertentu adalah skor UKG dengan batasan 65. Guru yang memperoleh skor di bawah 65 untuk kelompok kompetensi tertentu wajib mengikuti program peningkatan kompetensi untuk kelompok kompetensi tersebut, baik dengan moda tatap muka, dalam jaringan (daring) murni/fully online, maupun daring kombinasi/blended learning (Kementerian Pendidikan Nasional, 2016).

Hasil pelaksanaan Program Guru Pembelajar tahun 2016 yang sudah dipublikasikan oleh Direktorat Jenderal Guru dan Tenaga Kependidikan (Dirjen GTK) menunjukkan adanya peningkatan kompetensi secara signifikan. Peningkatan tersebut terjadi pada seluruh tingkat baik SD, SMP, SMA, dan SMK secara nasional. Namun, dalam peningkatan tersebut belum ada penjelasan lebih rinci mengenai capaian kompetensi untuk masing-masing mata pelajaran pada semua jenjang.

PPPPTK sebagai pelaksana program guru pembelajar mengevaluasi pelaksanaan program tersebut melalui informasi hasil pelaksanaan Program Guru Pembelajar untuk masing-masing mata pelajaran dan jenjang yang dibutuhkan. Demikian juga dengan PPPPTK Pendidikan Kewarganegaraan dan Ilmu Pengetahuan Sosial (PPPPTK PKn IPS) yang membutuhkan informasi mengenai tingkat keberhasilan pelaksanaan Program Guru Pembelajar untuk mata pelajaran tersebut, termasuk mata pelajaran IPS SMP. Informasi ini dapat dijadikan sebagai dasar untuk melaksanakan perbaikan dan peningkatan dalam melaksanakan program-program pengembangan kompetensi guru mata pelajaran IPS SMP. Oleh karena itu, penelitian yang dilakukan ini membatasi kajiannya pada mata pelajaran IPS SMP. 
Komunitas belajar secara daring memiliki kelebihan untuk membangun proses pembelajaran yang meningkatkan kemampuan berpikir peserta melalui diskusi-diskusi berkelanjutan dan refleksi yang dilakukan peserta seperti halnya pada komunitas belajar secara tradisional (tatap muka), tetapi apakah proses yang demikian dapat menunjang peningkatan hasil belajar masih menjadi tantangan untuk terus dikaji (Akyol \& Garrison, 2011). Penelitian ini akan memfokuskan pada dampak Program Guru Pembelajar yang dilakukan dengan moda daring, baik murni maupun kombinasi terhadap peningkatan kompetensi guru-guru IPS SMP.

Dalam Pedoman Umum Guru Pembelajar (Kementerian Pendidikan Nasional, 2016) disebutkan terdapat 3 jenis moda yang dapat diikuti guru peserta program guru pembelajar. Guru dengan skor di bawah 65 (merah) pada 810 kelompok kompetensi (modul) diarahkan mengikuti program peningkatan kompetensi guru pembelajar dengan moda tatap muka (moda TM). Guru dengan skor di bawah 65 (merah) pada 5-7 kelompok kompetensi (modul) diarahkan untuk mengikuti moda dalam jaringan (daring) kombinasi, disebut dengan moda darkom/blended learning. Sedangkan guru yang memperoleh skor di bawah 65 pada 3-4 kelompok kompetensi (modul) akan mengikuti Program Guru Pembelajar dengan moda dalam jaringan (daring) murni, atau disingkat daring/fully online. Adapun guru yang memperoleh skor di bawah 65 hanya pada 0 sampai 2 kelompok kompetensi (modul), mereka dapat dinominasikan untuk menjadi narasumber nasional (pengampu) atau instruktur nasional (mentor) guru pembelajar. Dengan demikian, terlihat bahwa dari masukan peserta program guru pembelajar berdasarkan hasil UKG, peserta yang mengikuti moda daring murni memiliki kompetensi awal yang paling tinggi dibandingkan dengan kelompok yang lain.

Moda daring murni (fully online) adalah moda pembelajaran jarak jauh di mana baik konten materi maupun sistem penilaian dilakukan secara daring dan berbasis internet. Moda daring kombinasi (blended/hybrid learning) adalah moda pembelajaran di mana konten materi disampaikan baik secara tatap muka maupun daring tetapi proporsi lebih besar dilakukan secara daring, termasuk forum diskusi antarpeserta (Kementerian Pendidikan Nasional, 2016).

Dalam Pedoman Umum Guru Pembelajar, moda daring dan darkom dilaksanakan dengan prinsip sosial konstruktivisme, yaitu para peserta secara kolaboratif membangun pengetahuan, pemahaman, dan keterampilan dalam menjalani program pelatihan tersebut. Kolaborasi merupakan faktor yang penting dalam membantu keberhasilan pelatihan guru (Duncan-Howell, 2010). Namun, dukungan lingkungan sosial dalam bentuk umpan balik dan refleksi sebagai dasar keberhasilan dalam pembelajaran daring perlu direncanakan dan dimoderasi dengan seksama (Gaspariè \& Peèar, 2016)

Pelatihan dengan moda daring baik murni maupun kombinasi dilakukan secara paket, di mana dalam satu paket pelatihan peserta mempelajari dua modul. Secara daring setiap modul dipelajari selama paling lama satu bulan. Perbedaan antara moda daring murni dan moda daring kombinasi adalah pada moda daring kombinasi terdapat jadwal tatap muka antara mentor dan peserta sebanyak tiga kali selama peserta mempelajari dua modul (kurang lebih dua bulan). Pada saat tatap muka tersebut, peserta dan mentor dapat berdiskusi secara langsung untuk membahas materi-materi yang belum dipahami.

Dengan moda daring diharapkan guru tidak perlu meninggalkan kewajiban mengajar di sekolah karena guru dapat melaksanakan pembelajaran setiap saat di luar jadwal mengajar. Fleksibilitas ini merupakan salah satu keunggulan pembelajaran dengan moda daring yang tidak terdapat pada moda tatap-muka (Jeffrey, dkk., 2014). Selain itu, moda daring memiliki durasi lebih lama dibandingkan dengan moda tatap muka. Guru dapat belajar sesuai dengan kesempatan dan gaya belajar masingmasing sambil tetap menyediakan kesempatan untuk berkolaborasi dan melakukan refleksi 
(Duncan-Howell, 2010). Penelitian DuncanHowell juga menemukan bahwa mayoritas peserta yang disurvei dari tiga kelompok pembelajaran daring menyatakan bahwa pembelajaran daring yang mereka ikuti sesuai dengan kebutuhan mereka (relevan) dan sesuai dengan apa yang mereka harapkan (efektif).

Terdapat bukti yang kuat bahwa pembelajaran dengan moda daring memiliki tingkat efektivitas/keberhasilan paling tidak sama dengan pembelajaran moda tatap muka (Nguyen, 2015). Nguyen juga mengungkapkan hasil reviu yang dilakukan oleh Departemen Pendidikan Amerika Serikat terhadap 45 hasil penelitian mengenai perbandingan antara pembelajaran daring dan tradisional/tatap muka (face to face). Hasil reviu tersebut menunjukkan pembelajaran dengan moda daring sedikit lebih berhasil daripada moda tatap muka. Perbedaan tersebut lebih terlihat ketika pembelajaran daring dikombinasi dengan tatap muka tetapi tidak ada perbedaan yang signifikan antara hasil belajar dengan moda daring murni dibandingkan dengan daring kombinasi.

Larson dan Sung (2009) dalam penelitiannya terhadap 168 mahasiswa yang menempuh mata kuliah Sistem Informasi Manajemen dengan tiga moda (tatap muka, daring, dan daring kombinasi) menyimpulkan bahwa tidak terdapat perbedaan hasil belajar di antara ketiga moda tersebut. Demikian pula dalam hal tingkat kepuasan dan efektivitas pembelajaran menurut responden. York (2008) juga menemukan bahwa tidak ada perbedaan di antara ketiga moda dalam penelitiannya terhadap mahasiswa yang menempuh mata kuliah Administrasi Pekerja Sosial. Membandingkan 15 mahasiswa magister kelas daring dengan 12 mahasiswa magister kelas darkom, Akyol dan Garrison (2011) menyimpulkan bahwa tidak terdapat perbedaan antara dua jenis moda tersebut. Empat aspek yang dikaji yang dikaji oleh Akyol dan Garrison yaitu: 1) capaian level kognitif yang diukur dari transkrip diskusi-diskusi daring, 2) persepsi peserta mengenai keberhasilan pembelajaran dan 3) tingkat kepuasan yang keduanya diukur melalui kuisioner, serta 4) Nilai akhir peserta.

Hasil berbeda ditemukan oleh Collopy dan Arnold (2009) dalam studinya terhadap 88 mahasiswa keguruan yang terbagi menjadi tiga kelas: daring murni, daring kombinasi dominan daring, dan daring kombinasi dominan tatapmuka. Collopy dan Arnold menemukan bahwa para mahasiswa pada dua kelas darkom secara signifikan belajar lebih baik daripada mahasiswa pada kelas daring murni. Namun, perlu diperhatikan bahwa pengukuran keberhasilan belajar pada penelitian tersebut tidak menggunakan tes, melainkan menggunakan kuesioner dengan skala Likert. Dengan demikian, kegiatan peningkatan kompetensi guru dengan moda daring, baik murni maupun kombinasi merupakan alternatif yang sangat menjanjikan, di samping pola tradisional tatap muka yang selama ini masih menjadi pilihan utama (Holmes, 2013).

Pembelajaran dengan moda tatap muka lebih efektif daripada pembelajaran dengan moda daring murni atau daring kombinasi jika materi pembelajaran tersebut memiliki muatan keterampilan teknis dan praktis yang dominan daripada keterampilan berpikir yang bersifat lebih abstrak (Senn, 2008). Materi program guru pembelajaran IPS SMP memiliki muatan keterampilan berpikir lebih menonjol daripada keterampilan teknis dan praktis sehingga jika dilaksanakan dengan moda daring tidak akan berdampak terhadap capaian hasil belajar peserta. Senn (2008) juga menegaskan bahwa komponen tatap muka pada moda daring kombinasi dapat meningkatkan efektivitas pembelajaran. Peserta berkesempatan untuk berkomunikasi secara lebih cepat dan efisien ketika bertemu langsung dengan fasilitator untuk mengatasi kendala-kendala yang dihadapi dalam pembelajaran. Pada moda daring kombinasi, pertanyaan-pertanyaan dan diskusi yang belum tuntas dalam sesi tatap muka dapat dilanjutkan secara daring (Collopy \& Arnold, 2009). Respon yang lambat dari fasilitator terhadap pertanyaan 
peserta jika moda pembelajaran dilakukan secara daring murni menjadi potensi kelemahan moda ini dibanding dengan moda daring kombinasi.

Program Guru Pembelajar ini baru diluncurkan pada tahun 2015 dan belum pernah dilakukan kajian atau penelitian mengenai capaian guru yang mengikuti program tersebut. Secara lebih khusus, perbedaan capaian antara guru-guru yang mengikuti pembelajaran dengan moda daring murni dan moda daring kombinasi (belum pernah diteliti. Tulisan ini akan mendeskripsikan capaian (performance) dari para peserta yang mengikuti Program Guru Pembelajar baik yang mengikuti moda daring murni maupun moda daring kombinasi. Tulisan ini juga akan mengulas perbedaan capaian (performance) antara guru yang mengikuti program peningkatan guru pembelajar moda daring murni dengan moda daring kombinasi. Perbedaan capaian belajar antara guru yang mengikuti moda daring murni dengan guru yang mengikuti moda daring kombinasi secara deskriptif akan diungkap. Selain itu, akan diungkap pula tingkat relevansi dan efektivitas kegiatan tersebut menurut guru yang menjadi peserta. Evaluasi peserta terhadap pelaksanaan Program Guru Pembelajar pada kedua moda tersebut secara kualitatif akan dikaji.

Berdasarkan uraian latar belakang masalah di atas, maka masalah yang dapat diidentifikasi pada penelitian ini adalah: 1) belum ada informasi dan penjelasan mengenai tingkat keberhasilan atau efektivitas pelaksanaan Program Guru Pembelajar untuk mata pelajaran IPS SMP; dan 2) belum ada kajian mengenai dampak dari penggunaan moda pembelajaran dalam melaksanakan Program Guru Pembelajar, khususnya moda daring murni dan daring kombinasi terhadap peningkatan kompetensi guru IPS SMP; dan 3) belum ada kajian mengenai perbandingan efektivitas antara penggunaan moda daring murni dan moda daring kombinasi dalam Program Guru Pembelajar mata pelajaran IPS SMP.

Untuk memfokuskan pembahasan pada kajian ini, dibuat rumusan masalah sebagai berikut: 1) apakah Program Guru Pembelajar yang dilaksanakan dengan menggunakan moda daring murni dan daring kombinasi berhasil meningkatkan kompetensi guru IPS SMP? 2) bagaimana perbandingan efektivitas antara moda daring murni dan daring kombinasi? dan 3) bagaimana persepsi peserta pelatihan mengenai pelaksanaan moda daring murni dan daring kombinasi?

Tujuan dari penelitian ini yaitu: 1) mengungkap apakah program guru pembelajar yang dilaksanakan dengan menggunakan moda daring murni dan daring kombinasi berhasil meningkatkan kompetensi guru IPS SMP; 2) membandingkan efektivitas antara moda daring murni dan daring kombinasi; dan 3) mendeskripsikan persepsi peserta pelatihan mengenai pelaksanaan moda daring murni dan daring kombinasi.

Penelitian ini akan memiliki tiga manfaat. Pertama, bagi Kementerian Pendidikan dan Kebudayaan, khususnya Direktorat Jenderal Guru dan Tenaga Kependidikan, dapat memperoleh informasi yang lebih rinci mengenai implementasi program guru pembelajar khususnya yang dilaksanakan dengan moda daring, sehingga kebijakan mengenai program ini melalui moda daring dapat terus ditingkatkan. Kedua, bagi PPPPTK PKn dan IPS, hasil-hasil dari penelitian dapat digunakan untuk memperbaiki sistem pelaksanaan moda daring murni/ kombinasi sehingga proses pembelajaran dapat berjalan dengan lebih lancer. Ketiga, bagi pengampu (widyaiswara) PPPPTK PKn dan IPS, informasi dari penelitian ini merupakan bahan evaluasi diri tentang kinerja selama bertugas sebagai pengampu moda daring murni/ kombinasi.

\section{METODE}

Studi ini menggunakan pendekatan gabungan (mixed method), yaitu menggabungkan antara metode kuantitatif dan kualitatif dalam menggunakan dan menganalisis data. Aspek kuantitatif dalam studi ini mencakup tiga analisis. Pertama, analisis statistika deskriptif 
terhadap capaian peserta program guru pembelajar yang diukur dari nilai tes sumatif sebanyak 4 kali (rerata) dan nilai tes akhir. Kedua, analisis perbedaan capaian peserta program guru pembelajar antara nilai UKG peserta daring murni sebelum dan sesudah mengikuti program guru pembelajar yang diukur dari a) nilai UKG peserta daring kombinasi sebelum dan sesudah mengikuti program guru pembelajar; b) nilai UKG peserta daring murni dan daring kombinasi setelah mengikuti program guru pembelajar; dan c) rata-rata nilai tes sumatif peserta moda daring murni dan daring kombinasi. Ketiga, analisis statistika deskriptif tingkat relevansi dan efektivitas program guru pembelajar moda daring murni dan moda daring kombinasi. Adapun aspek kualitatif dalam studi ini mencakup analisis terhadap pendapat atau komentar peserta progam guru pembelajar mengenai program yang mereka ikuti dan usulanusulan perubahan agar program tersebut

Tabel 1 memperlihatkan populasi dari studi ini. Populasi adalah guru-guru IPS SMP peserta Program Guru Pembelajar moda daring murni dan moda daring kombinasi di Pulau Jawa. Sampel studi ini melibatkan 818 peserta yang terdiri dari 404 peserta daring murni dan 414 peserta daring kombinasi. Peserta daring murni sebanyak 404 terdiri dari 40 dari Jawa Barat, 20 dari Banten, 40 dari Jawa Tengah, 281 dari Jawa timur, dan 23 dari DKI Jakarta. Adapun 414 peserta daring kombinasi hanya berasal dari propinsi Jawa Barat dan Jawa Timur, masingmasing sejumlah masing-masing 151 dan 263 peserta. Jumlah yang hampir sama antara peserta dua moda ini adalah kondisi ideal untuk membandingkan efektivitas kedua moda.
Modul yang digunakan sebagai bahan kajian adalah modul kelompok kompetensi (KK) E yang dipelajari oleh peserta dari kedua moda. Modul KK E membahas Kajian Ekonomi dalam IPS Terpadu untuk kompetensi profesional dan pengembangan instrumen penilaian non-tes untuk kompetensi pedagogik. Modul kelompok kompetensi E dipilih untuk dilatihkan dalam moda daring murni dan daring kombinasi karena dari analisis data hasil UKG 2015 modul ini merupakan salah satu modul dengan nilai terendah.

Data kuantitatif dalam studi ini berasal dari Sistem Informasi Manajamen Guru Pembelajar (SIM GP) tahun 2016. Data tersebut berupa skor hasil tes sumatif sebanyak 4 kali dan tes akhir, serta data kuesioner skala 4 mengenai tingkat relevansi dan efektivitas program guru pembelajar. Data-data tersebut dianalisis secara deskriptif kuantitatif dengan mengukur rerata dan standar deviasi serta dengan memberikan gambaran visual dalam bentuk diagram batang.

Analisis perbandingan dilakukan antara: 1) nilai UKG 2015 modul E dengan nilai UKG 2017 modul E peserta moda daring murni; 2) nilai UKG 2015 modul E dengan nilai UKG 2017 modul E peserta moda daring kombinasi; 3) nilai UKG 2017 modul E peserta moda daring dan nilai UKG 2017 modul E peserta moda daring kombinasi; dan 4) nilai tes sumatif 2017 modul E peserta moda daring dan nilai tes sumatif 2017 modul E peserta moda daring kombinasi.

Analisis perbandingan dilakukan dengan teknik analisis $t$-test (uji beda). Semua analisis kuantitatif dilakukan dengan bantuan program microsoft excel. Analisis tingkat relevansi dan efektivitas juga dilakukan dengan mengukur rerata skor jawaban kuesioner.

Tabel 1 Reseponden Penelitian

\begin{tabular}{lcccccc}
\hline \multirow{2}{*}{ MODA } & \multicolumn{6}{c}{ Propinsi } \\
\cline { 2 - 7 } & Banten & DKI & Jawa & Jawa & Jawa & JUMLAH \\
\hline DARING & 20 & 23 & 40 & 40 & 281 & 404 \\
DARKOM & - & - & 151 & - & 263 & 414 \\
\hline \multicolumn{6}{c}{ Total responden } & \\
\hline
\end{tabular}


Data kualitatif adalah hasil jawaban/respon peserta berupa uraian atas pertanyaan terbuka dari kuesioner yang menanyakan tentang apa yang mereka sukai dari program yang mereka ikuti dan usulan-usulan perubahan agar program tersebut menjadi lebih baik. Data-data kualitatif tersebut dianalisis dengan menemukan pola-pola jawaban/respon yang berulang, sehingga dapat memberikan gambaran yang mendalam mengenai pelaksanaan program guru pembelajar dengan moda daring dan darkom dari sudut pandang peserta program tersebut.

\section{HASIL DAN PEMBAHASAN}

Dampak Program Guru Pembelajar yang dilaksanakan dengan menggunakan moda daring murni dan daring kombinasi dalam meningkatkan kompetensi guru IPS SMP.

\section{Analisis Deskriptif}

Hasil analisis deskriptif program guru pembelajar moda daring dan daring kombinasi disajikan dalam
Tabel 2.

Dalam bentuk diagram data-data hasil program guru pembelajar baik pada moda daring murni (DM) maupun moda daring kombinasi (DK) disajikan dalam Gambar 1.

Rerata skor UKG 2015 peserta daring murni untuk modul E adalah 41.81, sedangkan untuk peserta daring kombinasi adalah 38.07. Selama mengikuti kegiatan Guru Pembelajar, peserta melaksanakan 4 kali tes sumatif yang dilakukan secara daring. Rerata tes sumatif modul E peserta daring murni adalah 77.4 sedangkan rerata skor peserta daring kombinasi adalah 78.5. Pada akhir pembelajaran, peserta mengikuti tes akhir modul E yang dilaksanakan di Tempat Uji Kompetensi (TUK) dengan skor rerata masing-masing untuk peserta daring murni dan daring kombinasi adalah 60.88 dan 54.06. Dengan demikian, kenaikan (gain) rerata skor setelah mengikuti program guru pembelajar adalah 19.07 untuk peserta daring murni dan 15.99 untuk peserta daring kombinasi.

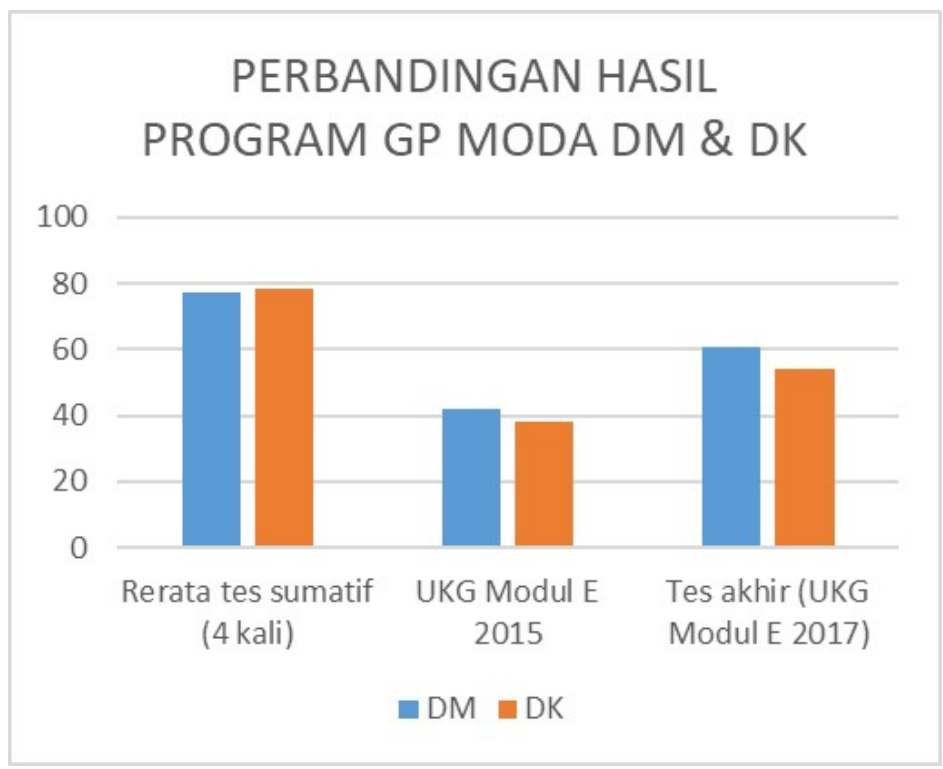

Gambar 1. Perbandingan Hasil Program Guru Pembelajar Moda Daring Murni dan Daring Kombinasi

Tabel 2 Analisis Deskriptif Program Guru Pembelajar

\begin{tabular}{ccccc}
\hline Moda & $\begin{array}{c}\text { Rerata tes } \\
\text { sumatif } \\
(4 \text { kali) }\end{array}$ & $\begin{array}{c}\text { UKG } \\
\text { Modul E } \\
2015\end{array}$ & $\begin{array}{c}\text { Tes akhir } \\
\text { (UKG Modul E } \\
2017)\end{array}$ & $\begin{array}{c}\text { Kenaikan UKG } \\
2015-2017\end{array}$ \\
\hline Daring Murni & 77,4 & 41,81 & 60,88 & 19.07 \\
\hline Daring Kombinasi & 78,5 & 38,07 & 54,06 & 15.99 \\
\hline
\end{tabular}




\section{Analisis Perbandingan}

Hasil analisis perbandingan ( $u j i$ beda) capaian hasil diklat guru pembelajar dengan moda daring murni dan moda daring kombinasi meliputi: perbedaan hasil tes akhir UKG 2017 modul E dengan UKG modul E 2015 masing-masing moda; perbandingan hasil tes akhir antara peserta moda daring murni dengan hasil tes akhir peserta moda daring kombinasi; dan perbedaan rerata tes sumatif antara peserta daring murni dan peserta daring kombinasi.

Analisis dengan menggunakan uji $t$ (alpha 0.05, 2 tails) menunjukkan terdapat perbedaan yang signifikan antara skor modul E peserta Guru Pembelajar moda daring murni sebelum mengikuti Program Guru Pembelajar (UKG 2015) dan skor sesudah mengikutinya (UKG tahun 2017) dengan nilai $p<0,05(0,00000000)$. Perbedaan signifikan antara UKG modul E 2015 dan UKG modul E tahun 2017 juga terjadi pada peserta guru pembelajar moda daring kombinasi. Hasil uji $t$ tersebut menunjukkan bahwa kenaikan skor UKG sebesar 19.07 pada moda daring murni dan 15.99 pada moda daring kombinasi bukan karena faktor kebetulan melainkan karena keikutsertaan para peserta pada Program Guru Pembelajar. Perbedaan signifikan itu juga menunjukkan bahwa telah terjadi peningkatan kompetensi guru peserta program guru pembelajar baik yang mengikuti moda daring murni maupun moda daring kombinasi. Dengan kata lain, Program Guru Pembelajar baik dengan moda daring murni dan moda daring kombinasi efektif meningkatkan kompetensi guru. Fakta ini menguatkan temuantemuan dari penelitian-penelitian terdahulu mengenai efektivitas diklat guru dengan moda daring murni dan moda daring kombinasi (Nguyen, 2015; Holmes, 2013; Duncan-Howell, 2010; Akyol \& Garrison, 2011).

\section{Perbandingan efektivitas antara moda daring murni dan daring kombinasi.}

Analisis uji $t$ skor tes akhir (UKG 2017) peserta moda daring murni dan moda daring kombinasi menunjukkan bahwa terdapat perbedaan yang nyata dalam hasil belajar dari peserta yang mengikuti moda daring murni dan hasil belajar peserta yang mengikuti moda daring kombinasi $(p<0.05, p=0.0000000)$. Terdapat selisih rerata skor sebesar $6.82(60.88$ - 54.06) di mana skor peserta daring murni lebih tinggi daripada skor peserta daring kombinasi. Hal di atas menunjukkan hasil yang berbeda dengan penelitian-penelitian yang telah dilakukan sebelumnya oleh Nguyen (2015), Akyol dan Garrison (2011), Larson dan Sung (2009), dan York (2008) mengenai efektivitas moda daring murni dan moda daring kombinasi. Penelitianpenelitian di atas menunjukkan bahwa tidak ada perbedaan hasil belajar antara peserta yang mengikuti pembelajaran moda daring murni dengan hasil belajar peserta dengan moda daring kombinasi. Walaupun Collopy dan Arnold (2009) menemukan dalam penelitiannya bahwa moda daring kombinasi lebih efektif daripada moda daring murni dalam meningkatkan hasil belajar,

Tabel 3 Analisis Perbandingan

\begin{tabular}{ll}
\hline \multicolumn{1}{c}{ Aspek yang dibandingkan } & $p$ value \\
\hline Nilai UKG modul E 2017 dan nilai UKG & 0.00000000 \\
2015 modul E moda daring murni & \\
\hline $\begin{array}{l}\text { Nilai UKG modul E 2017 dan nilai UKG } \\
2015 \text { modul E moda darkom }\end{array}$ & 0.00000000 \\
\hline $\begin{array}{l}\text { Nilai UKG modul E } 2017 \text { moda daring } \\
\text { murni dan moda darkom }\end{array}$ & 0.00000000 \\
\hline $\begin{array}{l}\text { Rerata tes sumatif } 2017 \text { modul E moda } \\
\text { daring dan daring kombinasi }\end{array}$ & 0.285 \\
\hline
\end{tabular}


pengukuran efektivitas moda dalam penelitian mereka tidak menggunakan tes tetapi menggunakan skala Likert, yaitu dengan mengukur persepsi peserta diklat.

Perbedaan antara penelitian ini dengan penelitian-penelitian di atas terletak pada penentuan peserta pembelajaran kedua moda tersebut. Pada penelitian-penelitian di atas mayoritas peserta adalah mahasiswa pada perguruan tinggi yang dikelompokkan menjadi beberapa kelompok untuk mempelajari topik tertentu dengan moda yang berbeda (Nguyen, 2015; Larson \& Sung, 2009; Senn, 2008; Akyol \& Garrison, 2011). Partisipan pada penelitian yang dilakukan oleh Duncan-Howell (2010) adalah guru-guru yang mengikuti kegiatan pengembangan profesi. Pada semua penelitian di atas responden dilibatkan secara acak tanpa memperhatikan kemampuan awal mereka, sehingga dapat dikatakan bahwa kemampuan awal antara mahasiswa dan guru yang mengikuti pembelajaran dengan moda daring murni dan daring kombinasi adalah relatif sama. Sementara pada penelitian ini, kemampuan awal peserta menentukan moda yang diikuti. Kemampuan awal peserta daring murni lebih tinggi daripada kemampuan awal peserta daring kombinasi. Perbedaan input peserta diduga kuat sebagai penyebab berbedanya skor tes akhir antara peserta moda daring murni dan daring kombinasi. Dengan demikian, meskipun terdapat perbedaan yang nyata antara hasil belajar peserta moda daring dengan hasil belajar peserta moda daring murni, hal tersebut tidak menunjukkan bahwa moda daring lebih efektif dari moda daring kombinasi.

Perbandingan rerata tes sumatif yang dilaksanakan masing-masing 4 kali untuk setiap moda, tidak menunjukkan adanya perbedaan yang nyata antara skor peserta daring murni $(77,4)$ dan skor peserta daring kombinasi $(78,5)$ dengan selisih skor 1,1 dan $p=0,285$. Tes sumatif dilaksanakan dengan cara yang berbeda dengan tes akhir. Tes akhir dilaksanakan oleh
PPPPTK secara terpusat pada Tempat Uji Kompetensi (TUK) yang telah ditentukan dengan didampingi oleh pengawas. Tes sumatif dilaksanakan secara mandiri oleh masing-masing peserta. Dari hasil diskusi dengan para peserta secara daring, mayoritas peserta baik pada moda daring murni maupun daring kombinasi melaksanakan tes sumatif secara bersama-sama sehingga memungkinkan mereka untuk bekerja sama dalam menjawab soal-soal tes tersebut. Hal ini menunjukkan bahwa telah terjadi kolaborasi antarpeserta dalam pembelajaran baik dengan moda daring maupun moda daring kombinasi yang mendukung keberhasilan belajar mereka. Dengan demikian kolaborasi telah menjadi salah satu faktor yang mendukung efektivitas pembelajaran baik pada moda daring maupun daring kombinasi sebagaimana yang disampaikan oleh Duncan-Howell (2010) dan Gaspariè \& Peèar (2016).

\section{Persepsi peserta pelatihan mengenai pelaksanaan moda daring murni dan daring kombinasi}

Persepsi peserta terhadap pelaksanaan Program Guru Pembelajar dengan moda daring murni dan daring kombinasi diukur dengan pendekatan kuantitatif dan kualitatif. Pendekatan kuantitatif berupa analisis tingkat relevansi dan efektivitas, sedangkan pendekatan kualitatif berupa jawaban atas pertanyaan-pertanyaan terbuka.

\section{Tingkat Relevansi}

Untuk mengukur tingkat relevansi Program Guru Pembelajar dengan pelaksanaan tugas guru di sekolah, diajukan dua pertanyaan menggunakan skala Likert 1-4.

1. Bagaimana Saudara menilai kesesuaian isi GP Daring ini dengan pekerjaan Saudara? (pertanyaan nomor 1 ).

2. Bagaimana Saudara menilai kegiatan ini berkaitan dengan kemampuan Saudara untuk menerapkannya pada pekerjaan Saudara? (pertanyaan nomor 6). 
Tabel 4. Relevansi relevansi Program Guru Pembelajar dengan pelaksanaan tugas guru di sekolah

\begin{tabular}{ccc}
\hline Moda & Daring Murni & Daring Kombinasi \\
\hline Relevansi & $86 \%$ & $91 \%$ \\
\hline
\end{tabular}

Dari tabel 4 dapat ditarik kesimpulan bahwa program guru pembelajar sangat relevan dalam membantu tugas-tugas guru, khususnya guruguru IPS SMP. Temuan ini sejalan dengan apa yang diungkap oleh Holmes (2013) dalam penelitiannya bahwa komunitas belajar yang dilaksanakan secara daring (murni dan kombinasi) dapat memfasilitasi guru untuk mengaplikasikan apa yang mereka pelajari ke dalam tugas mengajar mereka sehari-hari. Dalam komunitas belajar itu, para guru saling berbagi pengalaman dan pengetahuan. Mereka berkesempatan untuk secara kritis merefleksikan praktik mengajar yang biasa mereka lakukan dan melihat aplikasi dari apa yang dipelajari pada konteks yang lain. Hal tersebut akan memperkaya wawasan dan ide sehingga dapat menciptakan proses pembelajaran yang semakin berkualitas. Penelitian ini juga memperkuat penelitian dari Duncan-Howell (2010), mengenai relevansi diklat moda daring dengan tugastugas mengajar guru.

\section{Tingkat Efektivitas}

Tingkat efektivitas menurut para guru peserta program tersebut diukur dengan empat pertanyaan di bawah ini menggunakan skala Likert 1-4.

1. Bagaimana Saudara menilai akses ke sistem GP daring? (pertanyaan nomor 2).

2. Bagaimana Saudara menilai kualitas materi pelatihan yang disediakan dalam GP daring ini? (pertanyaan nomor 3 ).

3. Bagaimana Saudara menilai dukungan pengampu/mentor dalam pembelajaran daring? (pertanyaan nomor 4).

4. Bagaimana Saudara menilai GP daring ini secara keseluruhan? (pertanyaan nomor 5).
Respon dari peserta baik daring murni maupun daring kombinasi dapat dilihat pada tabel 5 .

Tabel 5 Tingkat Efektivitas Program Guru Pembelajar

\begin{tabular}{ccc}
\hline Moda & Daring Murni & Daring Kombinasi \\
\hline Efektivitas & $74 \%$ & $91 \%$ \\
\hline
\end{tabular}

Hasil tabel 5 menunjukkan bahwa menurut para peserta, Program Guru Pembelajar ini efektif (berhasil) meningkatkan kompetensi mereka. Hal tersebut telah terbukti dari hasil tes (UKG) sebelum dan sesudah dilaksanakannya Program Guru Pembelajar. Dengan demikian, efektivitas dari program ini dapat dibuktikan baik dari persepsi peserta program maupun secara empirik dari hasil tes. Kesesuaian antara hasil tes dan persepsi peserta terhadap efektivitas/keberhasilan moda daring dan daring kombinasi ini sejalan dengan hasil penelitian Akyol dan Garrison (2011).

Pada moda daring murni, dari empat aspek yang ditanyakan terkait dengan efektivitas Program Guru Pembelajar, aspek yang paling rendah adalah dukungan mentor/pengampu dalam pelaksanaan moda daring dengan skor $55 \%$. Hal ini terjadi karena dalam pelaksanaan para pengampu menangani jumlah peserta yang sangat besar. Beberapa pengampu bahkan menangani lebih dari 1.400 peserta per pengampu yang terbagi dalam 6-7 kelas daring penuh dan dua kelas daring kombinasi. Kondisi ini tentu sangat jauh dari ideal untuk sebuah pembelajaran.

Untuk pembelajaran daring murni/daring kombinasi dengan desain sosial-konstruktivistik di mana pembelajaran dapat efektif dengan adanya interaksi pengampu-peserta dan kolaborasi antarpeserta, maka kelas yang kecil menjadi syarat dengan rasio pengampu : peserta maksimal 1: 20 (Taft, Perkowski, \& Martin, 2011). Jumlah peserta yang besar yang harus ditangani oleh seorang pengampu mengakibat- 
kan respon dan umpan balik dari pengampu untuk para peserta, khususnya peserta daring murni, tidak bisa maksimal.

Kondisi di atas tidak terjadi pada moda daring kombinasi karena pada moda ini mentor (instruktur nasional) dilibatkan untuk mendampingi para peserta program guru pembelajar moda daring kombinasi. Rata-rata rasio antara mentor dan peserta adalah 1:30. Pada moda daring kombinasi ini respon peserta pada pertanyaan nomor 3 di atas adalah $93 \%$. Perbedaan yang sangat signifikan ini $(93 \%$ $55 \%=37 \%$ ) sangat wajar karena menurut Kuo dan Belland (2016) salah satu faktor penting penentu tingkat kepuasan peserta pembelajaran secara daring (baik penuh maupun kombinasi) adalah interaksi yang intens antara peserta dan pengampu.

\section{Analisis Kualitatif}

Untuk menganalisis secara kualitatif pelaksanaan dari Program Guru Pembelajar, telah disusun empat pertanyaan terbuka. Respon dari peserta dianalisis dengan melihat pola-pola dan tema-tema yang muncul dari jawaban-jawaban peserta, baik dari moda daring murni maupun moda daring kombinasi. Berikut respon para peserta untuk masing-masing pertanyaan yang diajukan:

1. Apa hal yang paling disukai peserta dari Program Guru Pembelajar?

Dari jawaban-jawaban yang disampaikan peserta, baik peserta daring murni maupun daring kombinasi, ada tiga hal yang paling disukai peserta dari Program Guru Pembelajar, yaitu materi pembelajaran, adanya kolaborasi antarpeserta, dan meningkatnya literasi Teknologi Informasi (TI) peserta. Tema dan pola jawaban ini terjadi baik pada moda daring murni maupun moda daring kombinasi.

Materi-materi yang digunakan dalam program guru pembelajar moda daring murni/ daring kombinasi kelompok kompetensi E (Kajian Ekonomi dalam IPS \& Instrumen Penilaian nonTes) dirasakan oleh sebagian peserta sangat membantu mereka dalam melaksanakan tugas mengajar mereka, khususnya mereka yang tidak berlatar belakang Sarjana Ekonomi.

Beberapa pernyataan peserta tentang materi pembelajaran adalah sebagai berikut.

"Hal yang saya sukai dari GP daring ini adalah bertambah pengetahuan mengenai Ilmu Ekonomi, karena saya bukan dari jurusan Ekonomi, tetapi dari jurusan Geografi. Dengan demikian, GP daring ini menambah khasanah ilmu pengetahuan saya mengenai IImu Ekonomi. Selain itu, saya menjadi lebih percaya diri ketika menerangkan pelajaran ekonomi di kelas dan ketika ada murid yang bertanya, saya bisa menjawabnya". (pernyataan peserta daring murni dari Jawa Barat).

"saya mendapat tambahan materi/ pengetahuan yang sangat bermanfaat menambah wawasan saya sebagai guru". (pernyataan peserta daring murni dari Jawa Tengah).

"Yang paling saya sukai dalam GP Daring ini adalah ketika membaca modul". (pernyataan peserta daring kombinasi dari Jawa Barat).

"Materi yang dipelajari lebih praktis dan efisien sehingga memudahkan untuk disalurkan kepada peserta didik". (pernyataan peserta daring kombinasi dari Jawa Timur).

Pola kolaborasi di antara peserta (community of inquiry) yang digunakan dalam pembelajaran moda daring murni dan daring kombinasi terbukti efektif untuk meningkatkan semangat dan hasil belajar peserta. Mereka memiliki kesempatan untuk bertukar pikiran dan pengalaman dengan teman sejawat tentang berbagai topik yang dibahas yang secara tidak langsung meningkatkan kompetensi mereka sebagai pendidik. Hal ini sesuai dengan apa yang diungkapkan oleh Holmes (2013) bahwa kolaborasi dalam pembelajaran daring merupakan sebuah bentuk community of inquiry yang memfasilitasi terjadinya refleksi kritis atas praktik pembelajaran, dukungan timbal balik antarpeserta, serta pemahaman yang lebih luas 
mengenai apa yang sedang dipelajari. Hal tersebut penting untuk pengembangan kompetensi dan mempersiapkan guru-guru untuk menghadapi masalah-masalah pembelajaran yang akan terjadi.

Pernyataan-pernyataan terkait dengan kolaborasi antarpeserta dalam mempelajari modul adalah sebagai berikut.

"Melalui GP online saya dapat berkomunikasi dengan guru lain melalui chatting". (pernyataan peserta daring murni dari DKI Jakarta).

"Dalam GP online ternyata terdapat program literasi, yang menuntut saya banyak membaca, kemudian menuangkan kembali di dalam tulisan (dalam Forum)". (pernyataan peserta daring murni dari Banten). "Yang paling saya sukai dari GP daring ini adalah saya bisa bertukar ilmu dan berdiskusi dengan guru-guru yang lain mengenai permasalahan yang dihadapi dalam GP daring". (pernyataan peserta daring kombinasi dari Jawa Timur).

Program Guru Pembelajar dengan moda daring murni dan daring kombinasi ini juga secara tidak langsung mengharuskan para guru peserta untuk meningkatkan kemampuan mereka dalam pemanfaatan teknologi informasi dan komunikasi. Literasi dalam bidang ini merupakan hal yang tidak bisa dihindari oleh siapapun dewasa ini jika mereka ingin meningkatkan kualitas diri. Para pendidik senantiasa dituntut untuk meningkatkan pengetahuan, keterampilan, dan profesionalisme mereka. Dengan penguasaan TIK yang lebih baik, tuntutantuntutan peningkatan tersebut dapat lebih mudah dicapai.

Berikut contoh pernyataan peserta terkait dengan peningkatan kemampuan dalam mengoperasikan TI adalah sebagai berikut.

"Saya semakin tertantang untuk lebih mengembangkan kemampuan TI yang dapat digunakan dalam pembelajaran di kelas". (pernyataan peserta daring murni dari Jawa Barat).
"Peningkatan kemampuan dalam mengoperasikan TI memperlancar penggunaan TI terhadap proses belajar mengajar di kelas, karena mau tidak mau peserta GP harus bisa menggunakan komputer serta menambah wawasan dan pengetahuan sehingga bisa meningkatkan kompetensi guru". (pernyataan peserta daring murni dari Jawa Timur).

"GP Daring bisa menambah wawasan dan pengetahuan saya sebagi seorang guru di samping itu dengan GP daring saya termotivasi untuk mengenal dan menguasai sistem informasi dengan menggunakan akses internet". (pernyataan peserta daring kombinasi dari Jawa Barat).

"dapat bersilaturahmi baik darat maupun dunia maya, sehingga sambil belajar mencari ilmu tentang teknologi, sehingga tidak gagap teknologi". (jawaban peserta daring kombinasi dari Jawa Timur).

2. Usulan-usulan perubahan agar Program Guru Pembelajar menjadi lebih baik.

Tema-tema utama yang muncul terkait dengan usulan-usulan perubahan pada program guru pembelajar adalah: 1) Learning Management System (LMS); 2) waktu pelaksanaan guru pembelajar; 3) peran mentor dan pengampu; serta 4) materi.

Banyak peserta baik moda daring murni maupun daring kombinasi yang mengalami kesulitan dalam menjalankan sistem pembelajaran dengan menggunakan LMS Moodle. Kesulitan tersebut antara lain terkait dengan inkonsistensi sistem dalam memberi tanda centang pada tugas-tugas yang sudah dikerjakan opeserta antara lain:

"Saya kesulitan dalam membuka forum sesi, walau anjuran mentor minimal dua rekan. Sudah dicoba namun hasilnya tidak terceklis. Begitu juga e-portofolio, dalam nilai sudah tercantum angkanya namun belum terceklis. Saat ini sudah bagus kami lanjutkan pembaharuan....". 
"Sistem pengiriman lembaran kerja harus ditinjau kembali karena saya mengalami kesulitan pada waktu pengiriman LK 1, tidak ada nilai hasil lembaran kerja, padahal pengiriman sudah dilakukan berulang".

Hal-hal di atas masih dapat dimaklumi mengingat Program Guru Pembelajar ini merupakan program besar yang melibatkan jutaan guru dari seluruh Indonesia yang baru berjalan kurang dari satu tahun. Namun demikian, keluhan para guru terkait sistem LMS tetap harus menjadi perhatian untuk dilakukan perbaikan dan peningkatan dalam hal konsistensi dan kemudahan dalam penggunaan, mengingat kemampuan/literasi komputer dan internet para peserta sangat beragam.

Sebagian peserta dari kedua moda menyoroti waktu pelaksanaan yang terlalu singkat, yaitu satu bulan untuk satu modul. Dengan waktu tersebut mereka terpaksa mengurangi konsentrasi untuk melaksanakan tugas mengajar sehari-hari di kelas dalam rangka mengerjakan tugas-tugas Program Guru Pembelajar. Beberapa peserta mengungkapkan agar tugas-tugas dalam Program Guru Pembelajar tidak mengganggu kegiatan belajar mengajar di sekolah masing-masing, materi pelatihan dan jadwal tidak berbenturan dengan jam mengajar. Selain itu, menurut mereka Program Guru Pembelajar daring cukup menyita waktu sehingga peserta didik banyak ditinggalkan.

Dengan moda daring atau daring kombinasi peserta seharusnya tidak meninggalkan atau mengurangi perhatian pada kegiatan mengajar sehari-hari karena disitulah letak keunggulan moda daring/daring kombinasi dibanding moda tatap muka (Jeffrey, dkk., 2014). Oleh karena itu, penyelenggara perlu mempertimbangkan waktu pelaksanaan program baik daring murni maupun daring kombinasi. Waktu satu bulan untuk satu modul dengan beban tugas yang terlalu banyak berakibat pada terbengkalainya tugas-tugas mengajar guru di kelas. Sebagai alternatif, jika waktu satu bulan untuk pembelajaran daring tetap dipertahankan, maka beban tugas (lembar kegiatan) yang harus dikerjakan peserta perlu ditinjau ulang agar lebih sesuai dengan alokasi waktu yang tersedia. Alternatif lain yaitu, jika beban tugas modul tidak dikurangi, maka alokasi waktu perlu diperpanjang, misalnya menjadi satu setengah bulan untuk setiap modul.

Berkaitan dengan mentor/pengampu, peserta meminta agar mentor/pengampu lebih dimaksimalkan, seperti membimbing dengan lebih detail, komunikasi yang lebih intensif dengan guru pengampu/mentor, dan tambahan tatap muka dengan mentor. Usulan-usulan ini berasal dari peserta daring murni, di mana masingmasing pengampu langsung membimbing peserta tanpa dibantu mentor. Sedangkan setiap pengampu moda daring murni membimbing antara 5 sampai 7 kelas dan masing-masing kelas terdiri dari 20-30 peserta. Keluhan peserta terkait hal ini tidak terjadi pada peserta moda daring kombinasi karena pada moda ini setiap pengampu membimbing paling sedikit 500 peserta dengan jumlah kelas antara 14-16 dan pengampu dibantu oleh seorang mentor untuk setiap kelas yang ada.

Usulan-usulan tersebut sejalan dengan nilai skor dari efektivitas Program Guru Pembelajar di atas. Pada aspek dukungan mentor/pengampu mendapatkan skor paling rendah dibanding aspek yang lain, 55\% untuk moda daring murni dan 93\% untuk moda daring kombinasi. Oleh karena itu, tindakan perbaikan yang perlu dilakukan adalah pertama, rasio mentor/pengampu dan peserta perlu dikurangi sehingga mentor/ pengampu dapat lebih maksimal memberikan bantuan dan bimbingan kepada para peserta. Rasio ideal adalah 1:20 (Taft, dkk., 2011). Kedua, pengampu dan mentor harus lebih proaktif dalam memberikan respon terhadap peserta, baik dalam hal substansi yang sedang dipelajari maupun dalam hal teknis LMS jika peserta mengalami kesulitan dalam melaksanakannya.

Usulan berikutnya mengenai perbaikan program guru pembelajar selanjutnya adalah terkait dengan materi. Walaupun dalam pengukuran efektivitas pelatihan guru 
pembelajar, pertanyaan mengenai kualitas materi mendapatkan skor cukup tinggi, yaitu di atas $85 \%$. Selain itu, mayoritas peserta juga mengakui bahwa materi yang disampaikan dalam Program Guru Pembelajar ini membantu mereka dalam melaksanakan tugas mengajar sehari-hari. Namun, beberapa peserta baik daring maupun daring komunikasi mengusulkan agar untuk semakin memudahkan pemahaman materi, perlu diperbanyak contoh-contoh konkret untuk setiap indikator. Berikut beberapa pernyataan dari peserta:

"Materi yang diberikan harus disertai dengan contoh yang cukup banyak, gunakan bahasa yang mudah dipahami dan lebih operasional, karena tidak semua guru yang ikut dalam daring ini mempunyai kemampuan yang sama dan rata". (pernyataan peserta darkom dari Jawa Barat)

"Modul agar lebih terinci lagi dan diperbanyak contoh-contoh terutama dalam instrumen penilaian". (jawaban peserta darkom Jawa Timur)

"Dalam penyajian setiap indikator materi agar diberi contoh yang mudah dipahami". (pernyataan peserta daring murni dari Banten).

"Penyajian materi supaya lebih baik dan gamblang, dan disertakan peta konsepnya". (pernyataan peserta daring murni dari DKI).

\section{SIMPULAN DAN SARAN}

\section{Simpulan}

Pelaksanaan Program Guru Pembelajar dapat disimpulkan efektif dalam meningkatkan kompetensi guru, baik dilakukan dengan moda daring maupun moda daring kombinasi. Hal tersebut telah dibuktikan dengan adanya perbedaan yang nyata antara nilai tes UKG sebelum dan setelah mereka terlibat pada program ini baik pada moda daring maupun darkom. Perbedaan yang nyata tersebut merupakan indikator bahwa pembelajaran yang dijalani oleh para peserta baik pada moda daring maupun darkom telah meningkatkan kompetensi mereka.
Penelitian ini juga menunjukkan bahwa skor tes akhir (UKG 2017) dari peserta moda daring secara signifikan lebih tinggi daripada skor tes akhir peserta moda daring kombinasi. Kondisi ini berbeda dengan mayoritas hasil penelitian terdahulu yang membuktikan bahwa tidak ada perbedaan antara hasil belajar yang dilakukan dengan moda daring dengan hasil belajar yang dilakukan dengan moda daring kombinasi. Hal ini tidak membuktikan bahwa moda daring lebih efektif daripada moda daring kombinasi, karena masukan (input) peserta moda daring memiliki kemampuan yang lebih tinggi daripada peserta moda daring kombinasi berdasarkan hasil UKG yang mereka peroleh pada tahun 2015. Perbedaan skor tes akhir tersebut dipengaruhi oleh kemampuan awal peserta yang berbeda. Hal ini dapat dibuktikan dari rerata skor tes sumatif yang dilakukan sebanyak empat kali pada kedua moda justru menunjukkan bahwa kedua moda sama-sama efektif, karena tidak ada perbedaan rerata skor tes sumatif di antara kedua moda tersebut.

Program Guru Pembelajar diakui oleh peserta, baik moda daring murni maupun moda daring kombinasi, sangat relevan dengan tugastugas mereka sebagai guru. Para peserta mengakui bahwa yang mereka peroleh dari program guru pembelajar ini dapat mereka aplikasikan dalam pembelajaran di dalam kelas. Relevansi program ini dengan tugas-tugas mengajar peserta secara lebih khusus dapat dilihat dari pernyataan-pernyataan para peserta saat mereka diminta melakukan evaluasi Program Guru Pembelajar.

Peserta juga menyatakan bahwa program Guru Pembelajar ini efektif dalam meningkatkan kompetensi mereka. Namun, terdapat perbedaan tingkat efektivitas yang cukup besar antara peserta moda daring murni dengan peserta daring kombinasi. Perbedaan ini disebabkan pada moda daring murni peserta merasa dukungan pengampu sangat minim sedangkan peserta daring kombinasi sangat puas dengan dukungan pengampu dan mentor selama pembelajaran. Penyebab dari kondisi di atas diduga kuat 
adalah rasio antara pengampu dan peserta yang terlalu besar sehingga perhatian pengampu kepada masing-masing peserta menjadi minim.

\section{Saran}

Beberapa hal yang perlu mendapatkan perhatian dari penyelenggara program pelatihan daring ini adalah, pertama, rasio pengampu/mentor dan peserta hendaknya disesuaikan dengan standar pelaksanaan pelatihan moda daring yaitu per pengampu/mentor membimbing maksimal 18-20 peserta. Hal ini perlu dilakukan agar pembelajaran yang terjadi dapat lebih maksimal.

Kedua, Learning Management System (LMS) yang digunakan perlu dibuat lebih konsisten sehingga peserta yakin dengan apa yang dikerjakan. Sistem yang digunakan diupayakan userfriendly mengingat para pengguna/peserta adalah para guru dengan usia yang beragam dan kemampuan IT yang bervariasi.

Ketiga, penyelenggara perlu memperhatikan keseimbangan antara jangka waktu pelaksanaan pelatihan moda daring/daring kombinasi dengan beban tugas yang harus dipenuhi oleh peserta. Tujuan pemilihan moda daring/daring kombinasi ini salah satunya adalah agar para guru tidak perlu meninggalkan kewajiban mereka dalam mengajar siswa di kelas sebagaimana jika pelatihan dilaksanakan dengan moda tatap muka. Namun, jika jangka waktu pelatihan daring/daring kombinasi sangat singkat dengan beban tugas yang banyak, justru akan mengganggu kewajiban guru dalam melaksanakan tugas utamanya.

\section{PUSTAKA ACUAN}

Akyol, Z., \& Garrison, D. R. (2011). Understanding cognitive presence in an online and blended community of inquiry: Assessing outcomes and processes for deep approaches to learning. British Journal of Educational Technology, 42(2), 233-250.

Collopy, R. M., \& Arnold, J. M. (2009). To blend or not to blend: online and blended learning environments in undergraduate teacher education. Issues in Teacher Education, 18(2).

Duncan-Howell, J. (2010). Teachers making connections: online communities as a source of professional learning. British Journal of Educational Technology, 41(2), 324-340.

Evans, D., Tate, S., Navarro, R., \& Nicolls, M. (2009). Teacher education and professional development in Indonesia a gap analysis. USAID.

Gaspariè, R. P., \& Peèar, M. (2016). Analysis of an asynchronous online discussion as a supportive model for peer collaboration and reflection in teacher education. Journal of Information Technology Education: Research, 15, 369-393.

Holmes, B. (2013). School teachers' continuous professional development in an online learning community: lessons from a case study of an eTwinning learning event. European Journal of Education, 48(1), 197.

Jeffrey, L. M., Milne, J., Suddaby, G. \& Higgins, A. (2014). Blended learning: how teachers balance the blend of online and classroom components. Journal of Information Technology Education: Research, 13, 121-140.

Kementerian Pendidikan Nasional. (2016). Pedoman Umum Guru Pembelajar. Jakarta: Direktorat Jenderal Guru dan Tenaga Kependidikan

Kuo, Y.-C., \& Belland, B. R. (2016). An exploratory study of adult learners' perceptions of online learning: minority students in continuing education. Education Technology Research Development. 64(4), 661-680.

Larson, D. K., \& Sung, C.-H. (2009). Comparing student performance: online versus blended versus faceto-face. Journal of Asynchronous Learning Networks, 13(1), 31-42. 
Nguyen, T. (2015). The effectiveness of online learning: beyond no significant difference and future horizons. MERLOT Journal of Online Learning and Teaching, 11(2), 309-319.

Republik Indonesia. (2007). Peraturan Menteri Pendidikan Nasional nomor 16 tahun 2007. Jakarta.

Senn, G. J. (2008). Comparison of face-to-face and hybrid delivery of a course that requires technology skills development. Journal of Information Technology Education, 7, 267-283.

Taft, S. H., Perkowski, T., \& Martin, L. S. (2011). A framework for evaluating class size in online education. The Quarterly Review of Distance Education, 12(3), 181-197.

York, R. O. March. (2008). Comparing three modes of instruction in a graduate social work program. Journal of Social Work Education, 44(2), 157-172. 